\title{
Allelic relationships of anthracnose (Colletotrichum lindemuthianum) resistance in the common bean (Phaseolus vulgaris L.) cultivar Michelite and the proposal of a new anthracnose resistance gene, Co-11
}

\author{
Maria Celeste Gonçalves-Vidigal, Claudete Rosa da Silva, Pedro Soares Vidigal Filho, \\ Adriana Gonela and Marcus Vinícius Kvitschal \\ Departamento de Agronomia, Universidade Estadual de Maringá, Maringá, PR, Brazil.
}

\begin{abstract}
The genetic resistance of Phaseolus vulgaris L. cultivar Michelite to races 8 and 64 of Colletotrichum lindemuthianum, causal agent of bean anthracnose, was characterized. Crosses were made between Michelite and Mexico 222 cultivars and the $F_{2}$ population was inoculated with race 64 in order to study the inheritance of resistance to anthracnose in Michelite. The segregation of $F_{2}$ population fitted in a ratio of 3R:1S, showing the presence of a dominant gene in Michelite gene conditioning resistance to race 64. Allelism tests were conducted with $F_{2}$ populations derived from crosses between Michelite and AB 136, AND 277, BAT 93, Cornell 49-242, G 2333, Kaboon, Mexico 222, Michigan Dark Red Kidney (MRDK), Ouro Negro, Perry Marrow, PI 207262, TO, TU, and Widusa. All the cultivars (except Mexico 222) were resistant to race 64. While $F_{2}$ derived from the Michelite $x$ Mexico 222 was inoculated with race 8 . Additionally, allelism tests indicated that the gene present in Michelite is independent from Co-1, Co-2, Co-3, Co-4, Co-5, Co-6, Co-7, Co-9 and Co-10 genes. The monogenic inheritance observed in Michelite and the independence of this gene from those previously characterized allow the authors to propose that the anthracnose resistant gene in Michelite should be named Co-11.
\end{abstract}

Key words: Colletotrichum lindemuthianum, gene pool, mesoamerican resistance gene, Phaseolus vulgaris L.

Received: June 7, 2006; Accepted: December 20, 2006.

\section{Introduction}

The common bean (Phaseolus vulgaris L.) is one of the most important components of the Brazilian diet as it is a proven source of protein and also a good source of carbohydrates and iron. Brazil is the largest producer of $P$. vulgaris (FAO, 2006), with the Brazilian state of Paraná being responsible for $25 \%$ of Brazilian production.

The yield of $P$. vulgaris can be affected by climatic conditions which can cause outbreaks of a large number of pests and diseases (Vieira, 1988). Among them, the anthracnose caused by Colletotrichum lindemuthianum is one of the most widespread and economically important fungal diseases of common bean (Phaseolus vulgaris L.), mainly occurring when plants are grown under high relative humidity and temperatures of between $13{ }^{\circ} \mathrm{C}$ and $26^{\circ} \mathrm{C}$. These climatic conditions favor infection by $C$. lindemuthianum which can cause losses in yield as high as $100 \%$ and, in less severe instances, lowering product quality by damaging the

Send correspondence to M.C. Gonçalves-Vidigal. Pós-Graduação em Genética e Melhoramento, Universidade Estadual de Maringá, Bloco 5, sala 1, 87020-900 Maringá, PR, Brazil. E-mail: mvidigal@ pop.com.br. pod and seed and thus affecting the value of the crop, sometimes even making it unfit for consumption.

Anthracnose is distributed worldwide and in Brazil more than 25 different $C$. lindemuthianum races have been identified (Rava et al., 1994; Thomazella et al., 2002). Farmers use a variety practices to prevent anthracnose in $P$. vulgaris, including the use of non-infected seeds, the application of fungicides to seeds and the aerial parts of plants, practice crop rotation and the rotation of planting dates (Vieira, 1988), although the most efficient practice to control the disease is normally to use resistant cultivars.

Several studies have identified anthracnose-resistance genes in different $P$. vulgaris cultivars, including Co- 1 (Kelly and Vallejo, 2004), Co- $1^{2}, C o-1^{3}$ (Melotto and Kelly, 2000), Co- $1^{4}$, (Alzate-Marin et al., 2003a), Co- $1^{5}$ (Gonçalves-Vidigal and Kelly, 2006), Co-2 (Mastenbroek, 1960), Co-3 (Fouilloux, 1976), Co-4² (Young et al., 1998), Co-5 (Young et al., 1998), Co-6 (Gonçalves-Vidigal, 1994; Kelly and Young, 1996), Co-7 (Kelly and Vallejo, 2004), Co-9 (Geffroy et al., 1999) and Co-10 (Alzate-Marin et al., 2003b). The Co-6 gene replaces the original symbol ' $Q$ ' proposed by Gonçalves-Vidigal (Ph.D. Thesis Universidade Federal de Viçosa, Viçosa, Brazil, 1994) for the gene 
conditioning resistance to $C$. lindemuthianum race 31 in $P$. vulgaris cultivar $\mathrm{AB} 136$.

The $P$. vulgaris Michelite cultivar (a 'navy bean' obtained by a breeding program at Michigan State University, USA), derived from a cross between the $P$. vulgaris cultivars Early Prolific and Robust, has a higher yield and better seed quality than the traditional $P$. vulgaris Robust cultivar. In addition, the Michelite cultivar is resistant to common strains of the bean common mosaic virus (BCMV) present in Michigan during that time (Down and Thayer, 1938).

Previous work has revealed that the Michelite differential cultivar showed different resistance mechanisms towards distinct physiological races of $C$. lindemuthianum. It was shown that this cultivar was resistant to races alpha, beta (130), gamma (102), 2, 4, 6, 36, 38, 64, 86, 96, 132, 256, 258, 264, 320, 384, 392, 448, 1088, 1344, 1472, 1600 and to some other races such as MA- 1 to MA-6, and MA-8 to MA-10 from the Mexican C. lindemuthianum groups (Yerkes Jr. and Ortiz, 1956; Cárdenas et al., 1964; Kelly et al., 1994; Balardin et al., 1997; González et al., 1998; Andrade et al., 1999; Sartorato, 2002). In Brazil, Michelite has also been shown to be resistant to $C$. lindemuthianum races 8, 64, 72, 102 (Rava et al., 1994).

The characterization of the anthracnose resistant gene present in the Michelite cultivar, as well as the allelism test between the gene found in this differential cultivar and the previously characterized genes, are of extreme importance to common bean breeders. The objective of this study was to determine the number of anthracnose resistance genes in the Michelite cultivar using $\mathrm{F}_{2}$ offspring populations derived from a cross with the susceptible cultivar Mexico 222 and also to determine the allelic relationships between the resistance gene(s) present in cultivar Michelite and the previously known $P$. vulgaris anthracnose resistance genes.

\section{Material and Methods}

\section{Plant material and cultivation of $F_{1}$ and $F_{2}$ seeds}

This work was conducted at the Núcleo de Pesquisa Aplicada à Agricultura (Nupagri) an extension of the Universidade Estadual de Maringá (UEM), Agronomy Department, from March, 2003 to November, 2004. Twelve differential Phaseolus vulgaris L. cultivars proposed by Pastor-Corrales (1991) and cultivars AND 277, BAT 93 and Ouro Negro were used in this study. Seeds from differential and commercial cultivars were obtained from Bean Gene Bank Nupagri. Parents were sown in pots containing soil previously fertilized and sterilized with methyl bromide in the greenhouse.

Crosses were made between the cultivar Michelite (the female parent in all crosses) and cultivars $\mathrm{AB} 136$, AND 277, BAT 93, Cornell 49-242, G 2333, Kaboon, Mexico 222, Michigan Dark Red Kidney (MRDK), Ouro Negro, Perry Marrow, PI 207262, TO, TU, and Widusa, the
Mexico 222 cultivar being susceptible (S) to $C$. lindemuthianum race 64 (CL64) and all the others resistant (R) to CL64. The experiment was conducted with four replications, each of them involving 15 plants from each parent, 15 plants from $F_{1}$ populations and $F_{2}$ populations, in order to evaluate their reaction to races 64 and 8 of $C$. lindemuthianum. Among the crosses, the Michelite (R) $\mathrm{x}$ Mexico 222 (S) cross was used to obtain information on the inheritance of resistance to CL64. The R x R crosses were conducted to test the independence between the gene present in the Michelite cultivar and other previously characterized genes.

$\mathrm{F}_{1}$ seeds were cultivated in pots with soil moisture previously sterilized and fertilized. Pots were kept in a greenhouse until pod maturation and harvesting. The $\mathrm{F}_{2}$ generation seeds were sown in trays containing soil (100 seeds in each tray). Plants were maintained in the greenhouse until the emergence of the first completely developed trifoliate leaf.

\section{Fungal isolates, inoculum preparation and plant inoculation}

The Colletotrichum lindemuthianum races 64 and 8 used in this work were provided by Aloísio Sartorato (Embrapa Arroz e Feijão - CNPAF, Caixa Postal 179, Santo Antônio de Goiás, GO) and João Bosco dos Santos (Universidade Federal de Lavras, Campus Universitário, Caixa Postal 37, Lavras, MG), respectively. The original race 64 isolate was obtained from leaves of the P. vulgaris Capixaba cultivar, found mainly in the Espírito Santo region of Brazil. According to Rava et al. (1994) race 64 belongs to the Mexican I C. lindemuthianum group.

Monosporic cultures of C. lindemuthianum of each race were transferred to test tubes containing the medium proposed by Mathur et al. (1950) and incubated at $20^{\circ} \mathrm{C}$ for 8 to 10 days. When sporulation began the cultures were stored at $5{ }^{\circ} \mathrm{C}$ until needed. The spores of $C$. lindemuthianum race 64 and 8 chosen for inoculation were obtained by culturing the fungi in pods partially immersed in an agar-agar culture medium according to the methodology proposed by Mathur et al. (1950) and Cárdenas et al. (1964). After each pod was contaminated with the fungi it was incubated for 14 days at $20{ }^{\circ} \mathrm{C}$ and the spores were transferred to a beaker containing sterilize distilled water to obtain a spore suspension which then filtered through a double layer of gauze order produce a suspension containing only spores. The spore suspensions were inoculated onto the anthracnose differential series of $P$. vulgaris cultivars Mexico 222 and Cornell 49-242 to confirm the race classification.

Fourteen day old seedlings with fully developed first trifoliate leaves were transferred to a mist chamber at approximately $100 \%$ humidity and $22{ }^{\circ} \mathrm{C} \pm 2{ }^{\circ} \mathrm{C}$. The parents, $\mathrm{F}_{1}$ and $\mathrm{F}_{2}$ generations from 14 crosses were inoculated with $1.2 \times 10^{6} \mathrm{~mL}^{-1}$ C. lindemuthianum spores using a De Vilbiss 
micro-atomizer, MS-2.3 (Schulz, JetMaster Schulz, Joinville, SC, Brazil) and seedlings kept in the same mist chamber for $96 \mathrm{~h}$ at $20^{\circ} \mathrm{C} \pm 2{ }^{\circ} \mathrm{C}$ and approximately $100 \%$ relative humidity under a $12 \mathrm{~h}$ light/dark photoperiod and 680 lux illumination during the light phase. After $96 \mathrm{~h}$ the seedlings were phenotypically evaluated for their disease reaction, using a 1 to 9 scale (Balardin et al., 1990). Plants with no visible disease symptoms or with only a few very small lesions, mostly on primary leaf veins, were recorded as resistant (scores 1 to 3 ) whereas plants with numerous enlarged lesions were recorded as susceptible (scores 4 to 9).

\section{Statistical analyses of data}

Observed to expect ratios were compared using the chi-square goodness of fit test $\left(\chi^{2}\right)$. The computer Genes program (Cruz, 2001) was used for this.

\section{Results}

\section{Inheritance resistance to race $C$. lindemuthianum 64}

The inheritance study showed that segregation in the $\mathrm{F}_{2}$ offspring from a cross between Michelite (R) x Mexico $222(\mathrm{~S})$ produced a $\mathrm{F}_{2}$ ratio of $3 \mathrm{R}: 1 \mathrm{~S}(\mathrm{p}=0.70)$, demonstrating that resistance to $C$. lindemuthianum race 64 in the Michelite cultivar is conferred by a dominant gene
(Table 1). Similar results were obtained by Cárdenas et al. (1964) when they inoculated a Michelite x MDRK cross $F_{2}$ offspring population with $C$. lindemuthianum race gamma.

\section{Allelism test}

All $\mathrm{F}_{1}$ plants behaved as resistant, indicating that resistance is dominant. The results from the segregation experiments carried out with $14 \mathrm{~F}_{2}$ offspring populations from crosses between the Michelite cultivar and other $P$. vulgaris cultivars are shown in Table 1.

Allelism tests showed segregation that fitted a ratio of 15 resistant (R) to 1 susceptible (S) plant in the $\mathrm{F}_{2}$ offspring from crosses between the Michelite cultivar and other cultivars (Table 1). This indicates the presence of two independent dominant genes conferring resistance to $C$. lindemuthianum, one of gene coming from the Michelite cultivar female parent and the other from the male parent.

The ratio of $63 \mathrm{R}: 1 \mathrm{~S}(\mathrm{p}=0.73)$, found in the $\mathrm{F}_{2}$ populations from the Michelite x PI 207262 and Michelite x Mexico $222(p=0.94)$ crosses indicates the segregation of three dominant genes, $\mathrm{Co}-4^{3}$ and $\mathrm{Co}-9$ from the PI 207262 cultivar, $\mathrm{Co}-3$ and a previously unidentified gene from Mexico 222 and the third gene in the Michelite cultivar (Table 1). Evidence for two independent genes in the PI 207262 cultivar comes from crosses with the differential cultivars Michelite, MDRK and Perry Marrow which pro-

Table 1 - The $F_{2}$ segregation from resistant $(\mathrm{R}) \mathrm{x}$ susceptible (S) and $\mathrm{R} \times \mathrm{R}$ Phaseolus vulgaris cultivar crosses for the genetic characterization of resistance to the phytopathogenic fungi Colletotrichum lindemuthianum races 8 and 64. Except for Mexico 222 (susceptible to race 64) all the parents in each cross were resistant to race 64 .

\begin{tabular}{|c|c|c|c|c|c|c|}
\hline \multirow[t]{2}{*}{$\mathrm{F}_{2}$ populations } & \multirow{2}{*}{$\begin{array}{l}\text { Known gene } \\
\text { (parent carrying the gene) }\end{array}$} & \multicolumn{2}{|c|}{ Number of plants $\mathrm{F}_{2}{ }^{\mathrm{c}}$} & \multirow{2}{*}{$\begin{array}{c}\begin{array}{c}\text { Expected } \\
\text { ratio }\end{array} \\
\mathrm{R}: \mathrm{S}\end{array}$} & \multirow{2}{*}{$\chi^{2}$} & \multirow[t]{2}{*}{$\mathrm{p}$ value } \\
\hline & & $\mathrm{R}$ & $\mathrm{S}$ & & & \\
\hline \multicolumn{7}{|l|}{ Inoculated with CL8 } \\
\hline Michelite $^{a}$ x Mexico 222 & Co-3 (Mexico 222) & 243 & 4 & $63: 1$ & 0.0052 & 0.94 \\
\hline \multicolumn{7}{|l|}{ Inoculated with CL64 } \\
\hline Michelite x Mexico 222 & Co-3 (Mexico 222) & 106 & 38 & $3: 1$ & 0.1481 & 0.70 \\
\hline Michelite $x$ MDRK $^{b}$ & Co-1 (MDRK) & 110 & 9 & $15: 1$ & 0.3501 & 0.55 \\
\hline Michelite x Kaboon & $\mathrm{Co}-1^{2}$ (Kaboon) & 96 & 7 & $15: 1$ & 0.0524 & 0.81 \\
\hline Michelite x Perry Marrow & $\mathrm{Co}-1^{3}$ (Perry Marrow) & 108 & 8 & $15: 1$ & 0.0827 & 0.77 \\
\hline Michelite x AND 277 & $\mathrm{Co}-1^{4}(\mathrm{AND} 277)$ & 99 & 4 & $15: 1$ & 0.9844 & 0.32 \\
\hline Michelite $\mathrm{x}$ Widusa & Co- $1^{5}$ (Widusa) & 158 & 8 & $15: 1$ & 0.5799 & 0.45 \\
\hline Michelite x Cornell 49-242 & Co-2 (Cornell 49-242) & 101 & 9 & $15: 1$ & 0.7006 & 0.40 \\
\hline Michelite x TO & Co-4 (TO) & 49 & 3 & $15: 1$ & 0.0205 & 0.88 \\
\hline Michelite x TU & Co-5 (TU) & 69 & 6 & $15: 1$ & 0.3920 & 0.53 \\
\hline Michelite x AB 136 & Co-6 (AB 136) & 75 & 5 & $15: 1$ & 0.0000 & 1.00 \\
\hline Michelite x BAT 93 & Co-9 (BAT 93) & 135 & 9 & $15: 1$ & 0.0000 & 1.00 \\
\hline Michelite x Ouro Negro & Co-10 (Ouro Negro) & 70 & 7 & $15: 1$ & 0.0024 & 0.96 \\
\hline Michelite x PI 207262 & Co- $4^{3}+\operatorname{Co}-9$ (PI 207262) & 155 & 3 & $63: 1$ & 0.1161 & 0.73 \\
\hline Michelite x G 2333 & $\mathrm{Co}-4^{2}, \mathrm{Co}-5, \mathrm{Co}-7$ (G 2333) & 282 & 1 & $255: 1$ & 0.010 & 0.92 \\
\hline
\end{tabular}

${ }^{a}$ In all cases the Michelite cultivar was the female parent and when Michelite and México 222 cultivars were inoculated with CL8 they showed a R x R reaction; ${ }^{b} \mathrm{MDRK}=$ Michigan Dark Red Kidney; ${ }^{\mathrm{c}} \mathrm{R}=$ resistant, $\mathrm{S}=$ susceptible. 
duced a two gene (15:1) segregation ratio after inoculation with $C$. lindemuthianum race 23 (delta) that overcomes the resistance in all three differential cultivars (GonçalvesVidigal et al., 1997). We found a four-gene segregation ratio $(255 \mathrm{R}: 1 \mathrm{~S}, \mathrm{p}=0.92)$ in the $\mathrm{F}_{2}$ population from the Michelite x G 2333 cross after inoculation with race 64 but no allelism was observed in this cross, although the segregation ratio supports the presence of four independent dominant genes with one gene in Michelite and three genes (Co-4 $4^{2}, \mathrm{Co}-5$ and $\left.\mathrm{Co}-7\right)$ in $\mathrm{G} 2333$ (Young et al., 1998). The segregation ratio of $15 \mathrm{R}: 1 \mathrm{~S}$ found by us in the $\mathrm{F}_{2}$ offspring from the Michelite $x$ MDRK $(p=0.55)$, Michelite $x$ Kaboon $(p=0.81)$, Michelite $x$ Perry Marrow $(p=0.77)$, Michelite x AND $277(\mathrm{p}=0.32)$ and Michelite x Widusa $(p=0.45)$ crosses, indicated that the gene in Michelite is independent from the genes previously characterized at the Andean $\mathrm{Co}-1$ locus $\left(\mathrm{Co}-1, \mathrm{Co}-\mathrm{I}^{2}, \mathrm{Co}-\mathrm{I}^{3}, \mathrm{Co}-\mathrm{I}^{4}\right.$ and $\left.\mathrm{Co}-\mathrm{I}^{5}\right)$.

It appears that the resistant gene in the Michelite cultivar segregated independently from the previously characterized Co-1, Co-2, Co-3, Co-4, Co-5, Co-6, Co-7, $\mathrm{Co}-9$ and $\mathrm{Co}-10$ dominant genes and is thus a newly identified gene (Table 1).

\section{Discussion}

The Michelite cultivar was the first bred variety, released by the Michigan State University in 1938, which was resistant to the common strains of bean common mosaic virus (BCMV) present in Michigan during that time (Down and Thayer, 1938) and also to several races of $C$. lindemuthianum. Our results show that the Michelite cultivar carries a dominant gene conferring resistance to $C$. lindemuthianum races 64 and 8 as well. The Michelite cultivar has been shown to carry resistance to $C$. lindemuthianum beta and gamma races (Yerkes Jr and Ortiz, 1956) and to the gamma race alone (Cárdenas et al., 1964; Rava et al., 1994).

Cárdenas et al. (1964) reported an adjusted resistance segregation ratio of $1 \mathrm{R}: 3 \mathrm{~S}$ in the $\mathrm{F}_{2}$ offspring from the Michelite $\mathrm{x}$ MDRK cross inoculated with $C$. lindemuthianum race beta, indicating reverse dominance. This was also reported when the segregating populations were inoculated with $C$. lindemuthianum race 130 (beta) (Cárdenas et al., 1964; Muhalet et al., 1981). Reverse of dominance can be the result of a multi-allelic series residing at the $C o-1$ locus in the MDRK cultivar with differing degrees of dominance existing between the alleles. However, the segregation observed in the populations from the Andecha x Mexico 222 crosses inoculated with $C$. lindemuthianum race 38 was produced a $\mathrm{F}_{2}$ segregation ratio of $3 \mathrm{R}: 1 \mathrm{~S}$, indicating the presence of a dominant resistance gene in the Mexico 222 cultivar (Méndez-Vigo et al., 2005). Muhalet et al. (1981) also observed reverse dominance in the $\mathrm{F}_{2}$ offspring from a Tuscola (R) $\mathrm{x}$ Montcalm (S) cross. Kelly and Vallejo (2004) have pointed out that reversal of dominance occurs in the same resistant cultivar due to dominance relationships between the alleles segre- gated in the population after inoculation with different races of the pathogen. As a result, recessive resistance is reported since the recessive allele confers resistance to the particular race of the pathogen to which the dominant allele is susceptible. This suggests that using different races to test $F_{2}$ offspring from the same crossing either a $3 R: 1 S$ or 1R:3S ratio would be observed depending on the virulent genes that the race possesses at the specific locus.

In our study, the lack of allelism in the $\mathrm{F}_{2}$ offspring from the Michelite x BAT $93(\mathrm{Co}-9)$ cross also implies the absence of $\mathrm{Co}-3$ allelism, since previous work showed that Co-3 and $\mathrm{Co}-9$ were allelic (Méndez-Vigo et al., 2005). We also found that the $F_{2}$ offspring from the Mexico $222 \mathrm{x}$ Michelite cross inoculated with C. lindemuthianum race 8 (which generates a $\mathrm{R} \times \mathrm{R}$ reaction in the parents) showed a $63: 1$ ratio $(\mathrm{p}=0.94)$ of resistant to susceptible plants. Vallejo and Kelly (2005) reported similar results in the $F_{2}$ population from a Mexico $222 \times$ MSU-7 cross (MSU-7 is a cultivar derived from the SEL 111 cultivar which carries Co-7 as its only anthracnose resistance gene) inoculated with $C$. lindemuthianum race 7, a race which yields a $\mathrm{R} \times \mathrm{R}$ reaction in the parents. In both studies, since $C$. lindemuthianum races 7 and 8 elicit an $\mathrm{R} \times \mathrm{R}$ reaction in the parents there must be two anthracnose resistance genes segregating from the Mexico 222 cultivar. Additional genetic inheritance studies are needed to confirm the existence of two genes in Mexico 222.

We found that the differential cultivar Michelite showed a monogenic dominant resistant spectrum to $C$. lindemuthianum race 64 and that the segregation of the $\mathrm{F}_{2}$ offspring from the Michelite and México 222 cross fitted a 3R:1S ratio, indicating the presence of a dominant $C$. lindemuthianum race 64 resistance gene in the Michelite cultivar since the México 222 cultivar is susceptible to race 64. In addition, our allelism tests indicated that the Michelite cultivar possesses one dominant gene segregating independently of the Co-1, Co-2, Co-3, Co-4, Co-5, Co-6, $\mathrm{Co}-7, \mathrm{Co}-9$ and $\mathrm{Co}-10$ genes. The combined results of the monogenic inheritance and the allelism tests support the hypothesis that only a single gene confers resistance to race 64 of C. lindemuthianum in Michelite, and that gene is independent of the other reported genes. We propose that the single dominant gene conferring resistance to anthracnose in the Michelite cultivar be named Co-11 (Gonçalves-Vidigal, 2005). A clear understanding of the nature and inheritance of anthracnose resistance in the Michelite cultivar should increase the availability of genes to transfer to commercial cultivars and could improve the effectiveness of resistance gene pyramiding for anthracnose in bean breeding programs.

\section{Acknowledgments}

This research was supported by grants from the Brazilian agency CNPq to M.C. Gonçalves-Vidigal and P.S. Vidigal Filho, and a grant from the Brazilian agency 
CAPES/ Prodoc to A. Gonela and C.R. Silva was supported by an undergraduate scholarship from Capes. The authors would like to express their gratitude to Dr. Aloísio Sartorato and Dr. João Bosco dos Santos for providing the isolates of $C$. lindemuthianum race 64 and 8 , respectively.

\section{References}

Alzate-Marin AL, Arruda KM de, Barros EG and Moreira MA (2003a) Allelism studies for anthracnose resistance genes of common bean cultivar AND 277. Ann Rep Bean Improv Coop 46:173-174.

Alzate-Marin AL, Costa MR, Arruda KM, Barros EG de and Moreira MA (2003b) Characterization of the anthracnose resistance gene present in Ouro Negro (Honduras 35) common bean cultivar. Euphytica 133:165-169.

Andrade EM, Costa JGC and Rava CA (1999) Variabilidade patogênica de isolados de Colletotrichum lindemuthianum de algumas regiões brasileiras. In: VI RENAFE - Reunião Nacional de Pesquisa de Feijão. Embrapa Arroz e Feijão, Salvador, pp 242-244.

Balardin RS, Jarosz A and Kelly JD (1997) Virulence and molecular diversity in Colletotrichum lindemuthianum from South, Central and North America. Phytopathology 87:1184-1191.

Balardin RS, Pastor-Corrales MA and Otoya MM (1990) Variabilidade patogênica de Colletotrichum lindemuthianum no Estado de Santa Catarina. Fitopatol Bras 15:243-245.

Cárdenas F, Adams MW and Andersen A (1964) The genetic system for reaction of field beans (Phaseolus vulgaris L.) to infection by three physiologic races of Colletotrichum lindemuthianum. Euphytica 13:178-186.

Cruz CD (2001) Programa Genes: Versão Windows; Aplicativo Computacional em Genética e Estatística. Editora UFV, Viçosa, 648 pp.

Down EE and Thayer JW (1938) The Michelite bean. Special Bull Mich Ag Expt Sta 295.

Fouilloux G (1976) Bean anthracnose: New genes of resistance. Ann Rep Bean Improv Coop 19:36-37.

Geffroy V, Delfine S, Oliveira JCF de, Sevignac M, Cohen S, Gepts P, Neema C, Langin T and Dron M (1999) Identification of an ancestral resistance gene cluster involved in the co evolution process between Phaseolus vulgaris and its fungal pathogen Colletotrichum lindemuthianum. Mol Plant-Microbe Interact 12:774-784.

Gonçalves-Vidigal MC, Cardoso AA, Vieira C and Saraiva LS (1997) Inheritance of anthracnose resistance in common bean genotypes PI 207262 and AB 136. Braz J Genet 20:5962.

Gonçalves-Vidigal MC and Kelly JD (2006) Inheritance of anthracnose resistance in the common bean cultivar Widusa. Euphytica 151:411-419.

González M, Rodriguez R, Zavala ME, Jacob JL, Hernandez F, Acosta J, Martinez O and Simpson J (1998) Characterization of Mexican isolates of Colletotrichum lindemuthianum by using differential cultivars and molecular markers. Phytopathology 88:292-299.

Kelly JD and Vallejo VA (2004) A comprehensive review of the major genes conditioning resistance to anthracnose in common bean. HortScience 39:1196-1207.
Kelly JD and Young RA (1996) Proposed symbols for anthracnose resistance genes. Ann Rep Bean Improv Coop 39:2024.

Kelly JD, Afanador L and Cameron LS (1994) New races of Colletotrichum lindemuthianum in Michigan and implications in dry bean resistance breeding. Plant Dis 78:892-894.

Mastenbroek C (1960) A breeding programme for resistance to anthracnose in dry shell haricot beans, based on a new gene. Euphytica 9:177-184.

Mathur RS, Barnett HL and Lilly VG (1950) Sporulation of Colletotrichum lindemuthianum in culture. Phytopathology 40:104-114.

Melotto M and Kelly JD (2000) An allelic series at the Co- 1 locus conditioning resistance to anthracnose in common bean of Andean origin. Euphytica 116:143-149.

Méndez-Vigo B, Rodríguez-Suárez C, Pañeda A, Ferreira JJ and Giraldez R (2005) Molecular markers and allelic relationships of anthracnose resistance gene cluster B4 in common bean. Euphytica 141:237-245.

Muhalet CS, Adams MW, Saettler AW and Ghaderi A (1981) Genetic system for the reaction of field beans to beta, gamma, and delta races of Colletotrichum lindemuthianum. J Amer Soc Hort Sci 106:601-604.

Pastor-Corrales MA (1991) Estandarización de variedades diferenciales y de designacion de razas de Colletotrichum lindemuthianum. Phytopathology 81:694.

Rava C, Purchio A and Sartorato A (1994) Caracterização de patótipos de Colletotrichum lindemuthianum que ocorrem em algumas regiões produtoras de feijoeiro comum. Fitopatol Bras 19:167-172.

Sartorato A (2002) Determinação da variabilidade patogênica do fungo Colletotrichum lindemuthianum (Sacc.) Scrib. In: $7^{\circ}$ Congresso Nacional de Pesquisa de Feijão, Congresso Nacional de Feijão, Viçosa, v 1, p 114-116.

Thomazella C, Gonçalves-Vidigal MC, Vidigal Filho PS, Nunes WMC and Vida JB (2002) Characterization of Colletotrichum lindemuthianum races in Paraná state, Brazil. Crop Breeding and Applied Biotechnology 2:55-60.

Vallejo V and Kelly JD (2005) Unexpected resistance genes for anthracnose uncovered. Ann Rep Bean Improv Coop 48:74-75.

Vieira C (1988) Perspectivas da cultura do feijão e de outras leguminosas de grão no país e no mundo. In: Zimmermann MJO, Rocha M and Yamada T (eds) Cultura do Feijoeiro. Editora ABPPF, Piracicaba, pp 3-20.

Yerkes Jr. WD and Ortiz MT (1956) New races of Colletotrichum lindemuthianum in Mexico. Phytopathology 46:564-567.

Young RA, Melotto M, Nodari RO and Kelly JD (1998) Marker-assisted dissection of the oligogenic anthracnose resistance in the common bean cultivar, "G 2333". Theor Appl Genet 96:87-84.

\section{Internet Resources}

FAO - Food Agricuture Organization (2006) Base de dados estatísticos. http://www.fao.org. Accessed in December 1, 2006.

Gonçalves-Vidigal MC (2005) New anthracnose locus, Co-11. http://www.css.msu.edu/bic/PDF/GeneticsCommittee

Minutes2005.pdf BIC Genetics Committee Minutes 2005, BIC Meeting Newark, Delaware.

Associate Editor: Everaldo Gonçalves de Barros 